\title{
Organizational Skills for a Corporate Citizen: Policy Analysis
}

\author{
INGO STOLZ \\ University of Minnesota \\ GARY N. MCLEAN \\ Texas A\&M University
}

\begin{abstract}
In a globalized world of retreating nation states and governments, corporations find themselves in the middle of society. A new organizational skill set is needed that enables corporations to position themselves as corporate citizens. It is the purpose of this study to identify a best practice to develop these organizational skills based on a policy analysis. The implementation of process structures is proposed as a best practice, and a 10-step approach for implementation is outlined. Also, implications for the field of human resource development and future research are discussed when considering issues of corporate responsibility and citizenship.
\end{abstract}

Keywords: Corporate Citizenship, Human Resource Development, Organization Development, Organizational Skills, Policy Analysis

In a globalized world of retreating nation states and governments (Aronowitz \& Giroux, 2000; Matten, Crane, \& Chapple, 2004; van Tulder \& van der Zwart, 2006), corporations find themselves in the middle of society (Burke, 2005; Detomasi, 2007; Keohane, 2008; Maerki, 2008) with a crucial role for society at large (Fourie \& Eloff, 2005; Hanson, 2006). A growing body of literature discusses the corporate stake in social cohesion (Logsdon \& Wood, 2002; Matten et al., 2004; Oketch, 2005; Waddock, 2004) and the new role of corporations as corporate citizens (Crane \& Matten, 2008; Marsden, 2000; Moon, Crane, \& Matten, 2005; Vidaver-Cohen \& Altman, 2000; Wood \& Logsdon, 2008). These discussions are not only mapping the territory of responsibilities and duties of corporations within society, regarding issues like globalization (Kobrin, 2008; Levy \& Kaplan, 2008; Scherer \& Palazzo, 2008; Zimmerli \& Holzinger, 2006), the environment (Gibbons, Lau, McAuliffe, \& 
Watson, 2007; Lai et al., 2007; Marsden, 2000), employment (Boris, Davis, Gross, Keintz, \& Totten, 2007; Cluff, Knuckle, Libaridian, Smith, \& Williams, 2007), justice (Young, 2006), equity (Cha, Cline, Liu, Meek, \& Villagomez, 2007; Curd, Julian, Sabow, \& Seligman, 2007), education (Arumugam, Craven, \& Statum, 2007), and health (Chan, Gupta, Palamountain, \& Saha, 2007; Greve, 2008; Sturchio, 2008; Vian, Richards, McCoy, Connelly, \& Feeley, 2007). These discussions also focus on the organizational skills needed to practice corporate citizenship (CC). Thus, the concept of CC has to be understood as both an outcome connected to the impact of corporate actions and a behavioral process that brings about these corporate actions. Post's (2000) definition best reflects this understanding and will be used in this article. Therefore, $\mathrm{CC}$ is defined as

[T]he process of identifying, analyzing, and responding to the company's social, political, and economic responsibilities as defined through law and public policy, stakeholder expectations, and voluntary acts flowing from corporate values and business strategies. Corporate citizenship involves actual results (what corporations DO) and the processes through which they are achieved (HOW they do it). (p. 29)

Only corporations with the necessary skills can show the commitment, willingness, and ability to take responsibilities and duties into account and fulfill their role as corporate citizens (Graafland \& van de Ven, 2006; Matten et al., 2004; Post, 2002). These skills are defined as the ability to nurture, develop, and frame processes that continuously create, evaluate, and verify CC practices inside the organization, thus finding ways for proactive, participatory, and vigilant considerations of collective responsibilities and systematic approaches of internal learning - which are continuously influenced by external experiences.

Leading corporations have begun to align the notion of $\mathrm{CC}$ with their strategic management goals and to develop the accompanying organizational skills (Leisinger, 2003; Manga \& Mirvis, 2005; Morsing \& Oswald, 2009; The Economist Intelligence Unit, 2008). This alignment is closely related to intraorganizational development programs for CC development. One example is the Swiss-based multinational pharmaceutical corporation, Novartis. With the goal to "integrate the principles of corporate citizenship into our business strategies" (Novartis, 2007, p. 2), Novartis has established the Integrity and Compliance Program to "foster awareness of and commitment to this [corporate citizenship] policy among our employees" and to "provide appropriate information and training to develop their skills" (p. 2). This effort is undertaken with the goal to "ensure that our principles are put into practice" (Novartis, 2008b) by "developing and maintaining an effective program which supports management in establishing, promoting and enforcing integrity and responsible decisionmaking" (Novartis, 2008a). As a consequence of these efforts, Novartis has been acclaimed for strong practices in the realms of $\mathrm{CC}$ by rating institutions like the Dow Jones Sustainability Index (2006), the FTSE (2006), the German Business Ethics Network (Aßländer, 2006), and Ethisphere (2007). 
Unfortunately, it has been shown that too few corporations have these organizational skills necessary to nurture, develop, and frame CC practices (Glazebrook, 2005; Pinkston \& Carroll, 1994; Poltauer, 2004; Welford, 2005). This absence not only leaves societal needs unconsidered (Lougee \& Wallace, 2008; Porter, 2008), but also harms the financial bottom line (Fussler, 2004; Lougee \& Wallace, 2008; van Beurden \& Gössling, 2008) and organizational functioning of corporations themselves (Lacy \& Pickard, 2008; Waddock \& Smith, 2000). Nevertheless, organizational structures (Fisher, 2001; Glazebrook, 2005; Kjonstad \& Willmott, 1995), leadership patterns in management (Bird \& Waters, 1989; Epstein \& Roy, 2001; Fisher, 2001; Grit, 2004; Smith, Simpson, \& Chun-Yao, 2007), a lack of awareness of key stakeholders (Fenwick \& Bierema, 2008; Glazebrook, 2005), often due to a lack of consideration of CC issues in business education programs (Sleeper, Schneider, Weber, \& Weber, 2006; Zlotkowski, 2004) as well as a lack of an appropriate rationale of how to nurture, develop, and frame CC practices (Hargett \& Williams, 2009; Porter, 2008; Waddock, 2004), continuously hamper these practices. This article will address the need to increase the organizational skills necessary by analyzing and proposing appropriate organizational intervention techniques through the means of a policy analysis.

\section{Analytical Approach, Stakeholders, Goals, and Objectives}

This analysis is driven by an interdisciplinary review of the research literature about CC from an organization development (OD) perspective. Based on this review, a best course of action of how corporations can attain the organizational skills to practice $\mathrm{CC}$ will be proposed. In a first step, the stakeholders that need to be considered in this realm will be highlighted. Furthermore, the goals and objectives that such a course of action should achieve will be specified.

The most crucial and powerful stakeholder is, arguably, senior management. Except in rare occasions, no change towards attaining organizational skills to practice $\mathrm{CC}$ can be initiated if top managers refuse their support. If those stakeholders do not take an active leadership role in all phases of the change process, the change process in general remains ineffective for the organization at large (Eisenbach, Watson, \& Pillai, 1999). The next most important stakeholders are probably mid-level managers and supervisors (Mirvis \& Manga, 2007). Mid-level managers and supervisors are ultimately responsible for ensuring that change processes are diffused inside the organization. It is at this organizational level that the organizational skills to nurture, develop, and frame CC practices actually begin to evolve and are stocked during the process (Bird \& Waters, 1989). Finally, employees are important stakeholders in the framework of this policy analysis. They not only have to buy into and trust the change processes initiated at higher organizational levels (Fisher, 2001), but they are also the stakeholders actually creating, evaluating, and verifying CC practices inside the organization (Epstein, 1989). 
The goal addressed in this policy analysis is to highlight the need to increase the organizational skills necessary for corporations to practice $\mathrm{CC}$ and to propose an OD intervention appropriate to develop these skills. Although there are a variety of reasons why too few corporations have the skills necessary, there is one common outcome of this lack of skills: they all inhibit employee involvement in the organizational setting. Employee involvement is crucial for the development of CC practices because it is the employees in general who enable the "institutionalization within business organizations of processes facilitating individual and organizational reflection and choice regarding the moral significance of personal and organizational action" (Epstein, 1989, p. 583). Only with the help of a broadly involved workforce is a corporation able to take the growing complexity of societal needs and consequences of business practices into consideration (Pirsch, Gupta, \& Grau, 2007; Waddock \& Smith, 2000), a move crucial for the creation, evaluation, and verification of CC practices inside the corporate setting. Therefore, corporations have to have the skills to nurture, develop, and frame these practices and processes of employee involvement to enable the creation, evaluation, and verification of CC practices.

\section{Methods}

It is the goal of this article to compare three human resource development (HRD) interventions that have the potential of developing the organizational skills necessary for practicing $\mathrm{CC}$ and to determine if one approach is better than the others. Four evaluative criteria will be used for this determination: (a) effectiveness of an intervention, (b) administrative ease to realize a particular intervention, (c) costs affiliated with an intervention, and (d) political constraints that are inherent in the choice of a particular intervention. All three HRD interventions under study will be scored according to each of these four criteria. It is now the purpose to present in detail how a scoring scheme for the criteria has been established.

\section{Effectiveness}

The proposition has been made that the forces hindering the development of organizational skills necessary for creating, evaluating, and verifying CC practices have a common impact: They all limit employee involvement in the organizational setting. Therefore, the effectiveness of an intervention that develops these organizational skills has to be referred to its predicted positive impact on employee involvement. To measure this degree of effectiveness across the alternative interventions analyzed in this article, the Survey of Employee Access of Teleometrics International (Hall, 2000) has been chosen. This 25-item tool measures the extent to which employees perceive being provided opportunities for employee involvement and according support systems. More specifically, the Survey of Employee Access assesses employee 
involvement using the following five subcategories: (1) access to problems, both inside and outside the organizational setting; (2) access to the people who are affected by or contribute to the problems; (3) access to information and resources; (4) access to support systems; and (5) access to the solution by having decision-making power. Each of these five subcategories is scored from 0 to 25 ; scores of 18 or higher are considered "excellent" for Subcategories 1 and 2, scores of 19 or higher are considered "excellent" for Subcategories 3,4 , and 5 (Hall, 2000). Internal consistency for all 25 items has been indicated by a Cronbach's alpha of 0.90 ; construct validity has also been indicated to be $\operatorname{good}(R=0.75, p<.001$; Hall, 2000).

The objective addressed in this policy article is that a particular intervention will lead to the best possible score of "excellent" for all five subcategories on the Survey of Employee Access within a time frame of 10 years. A score between 5 and 1 will be given for each of the five subcategories, with a score of 5, indicating the highest likelihood that a particular intervention will lead to such an "excellent" result within 10 years and a score of 1 if such an "excellent" result is highly unlikely. The five individual subcategory scores are summed and then divided by 5 to compute a mean effectiveness score for each intervention (Table B1 in Appendix B).

The time frame of 10 years has been chosen to allow changes to have an impact on the results of the Survey of Employee Access (Hall, 2000) and is a middle ground regarding estimated time frames as stated in the literature. The literature itself is unsure which time frame is feasible to expect results from. Nevertheless, it has been stated that such profound changes in employee involvement require between 6 and 15 years (Lau, Kilbourne, \& Woodman, 2003).

\section{Administrative Ease}

Administrative ease is defined as the magnitude of change needed in each of the following five organizational subsystems to implement a particular intervention: (a) Management Systems, (b) Training Systems, (c) Performance Management Systems, (d) Information Systems, and (e) Selection Systems. Administrative ease therefore projects the extent to which these subsystems would have to be changed if a particular intervention were chosen. A scale from 5 to 1 is used for each of the organizational subsystems; with a score of 5 indicating the highest degree of administrative ease if a particular intervention were chosen, a score of 1 indicating the lowest degree of administrative ease. The five subsystem scores are summed, and the sum is then divided by 5 to provide a mean administrative ease-score for each intervention (Table B2 in Appendix B).

\section{Cost}

The criterion, cost, consists of two components, both of which refer to the same five organizational subsystems as the criterion, administrative ease. First, 
cost measures the amount of money initially spent to initiate and implement the change processes needed within the five organizational subsystems if a particular intervention were chosen. Second, this criterion also refers to the long-term cost attributed to a particular intervention. Two individual scores for cost are given for each intervention under study. First, the overall cost for change within the five subsystems to initially implement a particular intervention is evaluated on a scale from 5 to 1 ; with a score of 5 indicating very low cost, and a score of 1 being very high cost. Then, the overall longterm financial consequences are evaluated on the same scale if a particular intervention were chosen. These two scores are summed and the sum is then divided by 2 to provide a mean cost-score for each intervention (Table B3 in Appendix B).

\section{Political Feasibility}

Political feasibility measures the degree to which a particular intervention would be supported or rejected by the three main stakeholder groups: Senior management, middle-management, and the employees. A PRINCE analysis (initially developed by: Coplin \& O'Leary, 1981; Coplin \& O'Leary, 1998; used here in adopted format developed by: Fowler, 2009, named after Machiavelli's political manifest, "The Prince") was conducted to compute a political feasibility score for each intervention. Applying a PRINCE analysis means that each of the three stakeholder groups were scored regarding three of their positions: (a) their issue position (expected resistance to or approval of a particular intervention), (b) their general power position within the organization, (c) and their priority position (how high of a priority a particular intervention is expected to be for a particular stakeholder group). For the issue position, a score between -3 and 3 is given for each stakeholder group; a score of -3 indicates strong resistance to a particular intervention, a score of -1 indicates weak resistance, a score of 3 indicates strong approval, and a score of 1 indicates weak approval. Both the power position and priority position are measured on a scale from 3 to 1 for each stakeholder group; with a score of 3 indicating a strong power position/ priority, a score of 1 indicating a weak power position/ priority. An overall score for the issue position regarding a particular intervention is computed by multiplying the three stakeholder group scores. The same is done to compute overall scores for power and priority position. The overall scores for issue, power, and priority position are then summed to receive a final score for political feasibility for a particular intervention. This final score is then converted to a scale from 5 to 1 in order to enhance the clarity by bringing the final score for political feasibility to a 5 to 1 scale as also used for effectiveness, administrative ease, and cost. The intervention with the highest political feasibility score is given a score of 5 . The scores of the other interventions are computed relative to the highest score. The calculations are shown in Table B4 in Appendix B. 


\section{Alternatives for Increasing Organizational Skills to Practice Corporate Citizenship}

Three alternative interventions were analyzed for this policy analysis: (a) establishment of parallel structures, (b) implementation of process structures, and (c) the creation of a high-involvement organization. This analysis entails the following policy instruments: (a) system change, (b) capacity building, (c) inducements, and (d) hortatory policy (McDonnell \& Elmore, 1987).

The three alternatives were derived from literature in the fields of $\mathrm{CC}$ and OD. Parallel structures regarding $\mathrm{CC}$ have been shown to be common, that is, in programs of volunteerism and philanthropy (Boston College Center for Corporate Citizenship, 2007; Genest, 2005). Process structures are one of the primary components of OD (McLean, 2006b), which again is a primary component of HRD (Cummings \& Worley, 2005). Also, process structures feature elements of both parallel structures and a high-involvement organization, combining and extending them in a unique way. Process structures, therefore, might be considered as in between the other two alternatives under study. Finally, the creation of a high-involvement organization has been asked for in recent CC literature, emphasizing the need for engagement and learning within the organizational context (Appels, van Duin, \& Hamann, 2006; Fenwick, 2007; Manga \& Mirvis, 2005; Maon, Lindgreen, \& Swaen, in press; Wilcox, 2006).

\section{Alternative I: Establishment of Parallel Structures}

Parallel structures operate next to and in conjunction with formal organizational structures. They provide employees with an alternative setting in which problems can be addressed and innovative solutions proposed, not restricted by the existing organizational structure and culture. Parallel structures can facilitate problem solving and change "by providing time and resources for members to think, talk, and act in completely new ways" (Cummings \& Worley, 2005, p. 310). Especially lower-level employees get the chance to be involved in an arena which is supported by senior and mid-level management (Honeycutt, 1989; Zand, 1974). Also, parallel structures are easy to implement and administer because the overall structure and culture remain unchanged, as do the performance management and selection systems; the adaptations needed of management, training, and information systems are minor and mostly only temporary (Majchrzak, Rice, Malhotra, King, \& Ba, 2000). This results also in low cost for the establishment of parallel structures. However, Cummings and Worley (2005) clearly defined the drawback of parallel structures: Management defines the conditions under which parallel structures operate, management does not give up decision-making power, and employees are typically restricted to making proposals and to offering suggestions. The impact on the indicators of the Survey of Employee Access is, therefore, rather low-especially regarding 
access to problems, access to people, and access to solution. Overall, parallel structures are characterized not only by low cost and high administrative ease, but also are limited in their effectiveness regarding increasing employee involvement.

Policy instruments. The establishment of parallel structures requires only a small amount of systems change because these structures are created alongside the formal organizational structure. It also requires only minor adaptations regarding capacity building, solely providing skills to facilitate meetings, and to work in teams (Zand, 1974). Inducements are not essential because reward systems remain unchanged. Hortatory policies, however, would be important, especially to address the common problem that the linkage between knowledge produced in parallel structures and its diffusion and use in the organization at large has proven to be often missing (Majchrzak et al., 2000). Hortatory policies, therefore, have to ensure that all members of the corporation get to know about the knowledge produced in parallel structures.

\section{Alternative 2: Implementation of Process Structures}

Process structures are more effective regarding employee involvement, but are also more difficult to implement within an organization than parallel structures. Process structures are the formation of multidisciplinary teams around core processes undertaken in a corporation (i.e., product development; Mohrman, Cohen, \& Mohrman, 1995). All functions necessary are placed in one work unit, with few hierarchical levels and departmental boundaries. These selfmanaged teams are composed of multiskilled members who perform interrelated tasks, typically responsible for a complete product or service. Employees are given the knowledge and power necessary to control their own task behaviors with relatively little external control and, therefore, have broad access to problems, people, resources, and decision-making power to be able to fulfill all functions necessary in the production cycle (Achrol, 1997). The key issue for management is boundary management: How to design the interface between self-managed teams and its environment.

The impact on effectiveness is high because employees have broad access to problems, people, decision-making power, information, and resources. However, process structures score low in administrative ease because the new functions require considerable changes in management systems, training systems, performance measurement systems, information systems, and selection systems (Cummings \& Worley, 2005). Also, the abandonment of hierarchies and the need for a new set of skills can especially threaten mid-level managers and supervisors (Cummings \& Worley, 2005; Herzig \& Jimmieson, 2006), reducing the political feasibility of this alternative. Despite these hindrances and the costs attributed to resolving them, senior management today nevertheless tends to be favorable regarding the introduction of process structures 
because long-term administrative costs can be reduced (Cummings \& Worley, 2005; Goodman, Devadas, \& Hughson, 1988).

Policy instruments. Systems change is essential when implementing process structures, as is the appropriate capacity building of management and employees to enable them to fulfill the new functions demanded by process structures. Furthermore, skill-based performance management systems have to be established (Lawler, Mohrman, \& Benson, 2001). However, the identification of the appropriate processes inside the corporation to form process structures around - and the appropriate change of management, training, and performance management systems thereafter-is often difficult to determine (Cummings \& Worley, 2005).

\section{Alternative 3: Creation of a High-Involvement Organization}

In high-involvement organizations, almost all organizational features are designed jointly by management and workers, including structure, work design, information and reward systems, and personnel policies. Therefore, highinvolvement organizations score high on effectiveness regarding employee involvement. However, the creation of a high-involvement organization scores low on administrative ease and political feasibility. Employees and management have to change fundamentally their way of perceiving, thinking, and behaving at work (Blumenthal \& Haspeslagh, 1994), which is resisted especially by midlevel management when having to give up power positions in favor of leaner structures and flatter hierarchies (Bird \& Waters, 1989; Cummings \& Worley, 2005; Fisher, 2001; Herzig \& Jimmieson, 2006). Broad changes in management and training systems are needed (Epstein, 1989; Grit, 2004; Zlotkowski, 2004), as are changes in performance management systems towards skillbased pay systems (Lawler et al., 2001) and in selection systems (Greiner \& Bhambri, 1989). Nevertheless, the creation of high-involvement organizations have increased over the past several years (Cummings \& Worley, 2005), mainly because of the financial long-term gains attributed to them (Guthrie, 2001; Pfeffer, 1995).

Policy instruments. The creation of high-involvement organizations necessitates system change and capacity building on a large scale. Reward systems and hortatory policies are equally affected. Nevertheless, due to possible financial gains, senior management is not unwilling to support the creation of highinvolvement organizations. However, financial gains cannot be expected in all situations. The creation of high-involvement organizations triggers complexity not all corporations are able to handle (Cummings \& Worley, 2005). Forrester (2000) gives an estimate of situational contingencies that seem to favor highinvolvement organizations: small organization size, new start-ups, and high quality products and services as an important determinant. 
The alternatives described above have different impact on the criteria, and no one alternative stands out. To select an effective alternative that is reasonable to administer and takes cost and political constraints into consideration, evaluative methods are needed. The next section discusses the strategy used to summarize and compare the alternatives.

\section{Evaluative Methods-The Strategy Used to Compare Alternatives}

The alternatives proposed are analyzed on the basis of the four criteria defined above by using a scorecard. The overall results of this analysis can be found in Appendix A. Each of the four criteria consists of two to five individual indicators, and the impact of each particular alternative on each indicator is determined based on the research literature (see Tables B1 to B4 in Appendix B). An overall score for each criterion is then computed based on the particular indicator scores. In a last step, the four criteria scores are summed to receive an overall final score for each alternative (Appendix A). In this last summation, the value of the effectiveness score is counted twice to emphasize the importance of the objective to enable corporations to achieve the best possible score of "excellent" (Hall, 2000, p. 8) for all five indicators on the Survey of Employee Access within a time frame of 10 years.

Looking at the total scores, it can be seen that the implementation of process structures attained the highest score (18.49), followed by the establishment of parallel structures (17.00) and the creation of a high-involvement organization (16.36). The alternative proposing the implementation of process structures, in this particular example, rose to the top due to the fact that it scored reasonably well across all four criteria in comparison with the other two alternatives. Establishing parallel structures is easy to administer with low costs and low political resistance, but effectiveness is also low. Creating a high-involvement organization is very effective, but also very difficult to administer with a high amount of political resistance. The implementation of process structures is almost equally effective while at the same time scoring higher on administrative ease; the costs and the political resistance are lower than if a high-involvement organization were created.

For the implementation of process structures, a very positive impact on the indicators of the Survey of Employee Access (Hall, 2000) can be projected, giving employees sufficient access to problems, people, resources and information, support, and decision-making power. Furthermore, the administrative changes are not as far-reaching as when a high-involvement organization would be created. Nevertheless, administrative challenges have to be mastered and initial high costs need to be considered.

This analysis is constrained, however, because some unintended consequences can emerge. Even if the resistance of mid-level management can be overcome, Herzig and Jimmieson (2006) emphasized that mid-level managers 
often experience problems trying to fulfill the complex demands of leading in process structures; a problem that has to be addressed through training or the hiring of new managers (Cummings \& Worley, 2005). Another problem is the fact that the identification of processes around which process structures can and should be created are sometimes difficult to determine, with the consequence of making the appropriate adaptation of management, training, performance management, information, and selection systems difficult (Cummings \& Worley, 2005). Also, the diffusion of knowledge created in a particular process structure inside the whole organization is difficult, sometimes leaving the corporation completely unaware of the existent expertise (Majchrzak et al., 2000). This results in redundancies and waste of energy, because solutions are recreated inside a particular corporation without being aware that this solution already existed within another process structure inside the overarching organizational structure (Cummings \& Worley, 2005). Therefore, when thinking about the implementation of process structures to increase employee involvement, these unintended consequences need to be considered and resolved.

\section{Discussion}

This policy analysis set out to propose ways for corporations to increase their organizational skills to enable them to practice CC. To increase these skills, the implementation of process structures has been proposed. To implement this sort of process structures in a corporation, the following 10-step approach is proposed; including the policy instruments of system change, capacity building, inducements, and hortatory policies. This 10-step approach is based on CC literature and also on propositions made in the literature about processes of OD and organizational change.

1. Senior management has to set the stage by sanctioning the efforts of implementing process structures and by granting legitimacy to the arenas in which this implementation will take place (Cummings \& Worley, 2005; Maon et al., in press; Purvis, Sambamurthy, \& Zmud, 2001).

2. With this legitimacy awarded from top, it is the middle and lower levels of the organization that should set out to analyze their work systems in order to discover how they are operating, so that well-designed process structures can be designed and implemented (Majchrzak et al., 2000; Manga \& Mirvis, 2005; Mirvis \& Manga, 2007; Nonaka, 1994).

3. Methods of control have to be diversified. Mid-level and line managers exercise outcome-based control in their work units during the implementation process, so that localized expertise and adaptations can be directly interrelated with the production processes of this particular unit, allowing knowledge to be created and integrated in the particular work processes. Senior management oversees the units' function with behavior-based control along the way, ensuring that the work units have the appropriate skills to actually interact with their fullest potential (Henderson \& Lee, 1992; Purvis et al., 2001).

4. Modes of change have to be diversified. Organizations very often change by adapting the whole organization through evolutionary and/ or life-cycle modes of 
change (van de Ven \& Poole, 1995). First, an evolutionary mode of change probably is a prerequisite for adopting process structures in the first place, replacing "old" structures and procedures. Organizations then often send their employees through predescribed and well-defined life-cycle stages in the adaptation process, including large investments in time for learning to occur and large amounts of money for training purposes. However, the awareness that new structures not only necessitate evolutionary and life-cycle modes of change, but also teleological changes with fast and small cycles of "goal formulation, implementation, evaluation, and modification of goals based on what was learned by the entity" (p. 520) is needed. Nevertheless, change taking place too fast and too frequently can "lead to random drift rather than improvement" (Levitt \& March, 1988, p. 334). The diversification of modes of change inside an organization therefore might make both continuous modification and thorough implementation possible.

5. Especially mid-level management requires new and different skills, including knowledge of process structure principles, group dynamics, understanding of both the task environment and the team's technology, and the ability to intervene in the team to help. Senior management has to sanction support systems with which midlevel management can acquire these necessary skills (Cummings \& Worley, 2005; Day, 2000; Hernez-Broome \& Hughes, 2004; Herzig \& Jimmieson, 2006).

6. Communities of practice as "social spheres between project teams and knowledge networks" (Allee, 2003, p. 123) have to be created, building a "system composed of a set of complex and overlapping task networks" (Mohrman, Klein, \& Finegold, 2003, p. 37) regarding CC. An organization has to be aware of these complex systems and has to nurture these communities by letting people define personal and collective roles. Time, space, and resources for employees to work together and to manage skills in a way that new roles can be defined have to be provided. This "generates both tangible and intangible value through complex dynamic exchanges" (Allee, 2003, p.192), thus establishing "system-wide social and cultural processes that enable individual employees and managers to grow" (Leskiw \& Singh, 2007, p. 453).

7. Performance management systems have to be established to reinforce the behaviors needed in process structures. Especially, mid-level management has to prepare skill-based developmental plans for individual employees and selfmanaged work-teams as a whole and set measurable benchmarks. Performance appraisal systems of mid-level managers, on the other hand, should be conducted in a group format, with feedback and involvement by team members, peers, and higher-level management within the community of practice (Cummings \& Worley, 2005; McLean, 2006b).

8. All members of the corporation have to be provided with information and data to be able to assess their work unit continuously and to make necessary changes and improvements. Communication systems have to be established in order to diffuse information and knowledge within the organizational setting accordingly (Cummings \& Worley, 2005; McLean, 2006b; Netteland, Wasson, \& Mørch, 2007).

9. Collaborative monitoring efforts continuously have to take place inside the organization. Agreed-on measures have to be established and provided to all organization members in the first year of the change effort in order to enable them to collaboratively monitor whether appropriate skills, resources, and information are provided and whether Management Systems, Performance Appraisal Systems, and Selection Systems are adapted to process structures. Even though monitoring is accomplished collaboratively, it is senior management that has to process, acknowledge, and feedback the results and make continuous adaptations based 
on them. Overall, processes of monitoring have to be installed in the daily business practices of the corporation to establish feedback loops that are not dependent on quarterly results or annual reports (Brinkerhoff, 2003; Holton III, 1996; Kirkpatrick, 1959, 2004; Phillips, 2007).

10. The evaluation of outcomes has to be initiated by senior management, but would best be administered by independent outside agents to ensure the impartial representation of the results (for external standards and certifying institutions see: Castka \& Balzarova, 2008; European Commission, 2006; OECD, 2001; United Nations, 2008; World Bank, 2008). Even though a time frame of 10 years was chosen for this analysis, evaluations should not only take place after this time period, but also should be undertaken in regular intervals. These evaluations could be administered every year and could be included in the annual report. For the purpose of these evaluations, the Survey of Employee Access (Hall, 2000) can again be used to assess whether the organization made progress towards reaching the objective. If problems became obvious, the results can be compared with those of the monitoring efforts to find solutions to further adapt and enhance the change process.

Having provided an extensive list of strategic interventions to increase the organizational skills necessary to practice CC, an important limitation of this list and this analysis has to be highlighted. It is especially the (inter)cultural aspects that are not sufficiently considered. The discussions about $\mathrm{CC}$ and the tools proposed to increase organizational skills to practice $\mathrm{CC}$ are implicitly referring to an economic setting as found in industrialized nations in a Western context. Also, different organizational cultures - shaped by various sources - are not accounted for. It is a challenge for future research and business practices to locate the discussions and tools in a global and cross-sectional arena, taking (inter)cultural aspects and divergent assumptions about the scope and role of the corporate sector in society as well as preexisting organizational dispositions into consideration.

\section{Implications for HRD and Future Research}

The authors of this article are aware of the fact that a rather new thread of argument is put forward within the field of HRD by proposing a best practice for developing organizational skills to practice CC. It is of course not uncommon that HRD occupies itself with complexities that come about by the fact that organizational entities are embedded in larger societal contexts; especially if it is taken for granted that organizational structures are becoming ever more permeable (Post, 2002). However, the target of impact that a particular study about these complexities would focus on mostly remains on the intraorganizational level; even though for example, employee involvement inherently has the potential to show impacts well beyond the organization by possibly enhancing the sheer well-being of an employee, thus also possibly showing positive consequences on family life, health, and so on. This article has proposed a best practice that enhances the organizational skills necessary to practice CC by enhancing employee involvement through the implementation of process structures. A 
rationale for this proposition has been given above. Nevertheless, it is important to note that by making this proposition, this article implicitly challenges the assumption identified by Crane and Matten (2008) "that corporations and citizenship are ontologically autonomous concepts, that citizenship is in some way independent from the values, actions, and impacts of corporations" (p. 31). Thus, the impact of this study in it's' essence really focuses on the complexities of larger societal contexts, of which corporations and their well-being are necessarily a part of. By choosing to have this kind of target of impact - and by generally considering corporations having an impact on "how we think about and valorize particular notions of citizenship" (Crane \& Matten, 2008, p. 32) - an argument is framed that views intraorganizational complexities from a slightly different perspective. It is not about how environmental complexities frame (intra)organizational processes and behaviors, it is about how organizational complexities have the potential of framing the social environment.

It has to be said that this approach is by no means all new. The awareness for the power of HRD tools within broader social systems has been acknowledged, notably in the realm of National Human Resource Development (McLean, 2004, 2006a). Nevertheless, establishing a systematic understanding for what that really means for HRD practice within a corporate setting has only just begun. Fenwick and Bierema (2008) state that HRD is so far "only marginally involved or interested" (p. 24) in this realm, even though they see HRD units as "well positioned" (p. 25) for that purpose, because it involves issues of HRD that are familiar.

Future HRD research therefore might first invest in coming to a clearer understanding about the impacts that HRD efforts might show regarding issues of corporate responsibility as well as regarding citizenship in general. Second, existing HRD tools and frameworks might be concretely applied to these issues - as undertaken by Foote and Ruona (2008) when discussing implications for HRD professionals when institutionalizing ethics, by Frisque and Kolb (2008) when analyzing the effect of training on office professionals when encountering ethical dilemmas, or by Hanson (2006) when investigating corporations' influence on national development and national identity.

\section{Conclusion}

This policy analysis has been undertaken with the conviction that the problem that too few corporations have the organizational skills necessary to practice CC needs to be addressed by HRD frameworks. The question has been asked about what strategies can be used to address this problem. It has been suggested that the establishment of process structures are a way to nurture, develop, and frame processes that continuously create, evaluate, and verify CC practices inside a corporation, thus developing these organizational skills necessary. A 10-step approach has been outlined to meet the challenges inherent in this approach. Also, the challenges that this kind of work most generally entails 
for HRD frameworks and research have been highlighted. In the end, a study has been brought forward that deals with nothing more and nothing less than with HRD's stake in citizenship and social cohesion.

\section{Appendix A \\ Overall Scorecard}

\begin{tabular}{lccccc}
\hline & \multicolumn{5}{c}{ Criterion } \\
\cline { 2 - 6 } Alternatives & Administrative & Political \\
(Packaging) & Effectiveness $(\times 2)$ & Ease & Costs & Feasibility & Total (Sum) \\
\hline Parallel structures & 3.6 & 4.40 & 4.00 & 5,00 & 17.00 \\
Process structures & 9.2 & 2.00 & 3.00 & 4.29 & 18.49 \\
$\begin{array}{l}\text { High-involvement } \\
\text { organization }\end{array}$ & 9.6 & 1.40 & 2.50 & 2.86 & 16.36 \\
\hline
\end{tabular}

NOTE: The alternative with the highest overall score will be chosen. The total is computed by summing up the individual criteria scores. The criteria effectiveness is counted twice.All scores are measured on a scale from I to 5 (this implies that the highest score for effectiveness is 10 , as this criterion is counted twice). For the criteria effectiveness and administrative ease, a higher score indicates a higher degree of effectiveness and administrative ease. For the criteria costs and political feasibility, a higher score indicates lower costs or lower political constraints respectively. See Appendix B for the computation of the individual criteria scores.

\section{Appendix B Individual Criteria}

TABLE BI: Criterion: Effectiveness (Hall, 2000)

\begin{tabular}{lcccccccc}
\hline & \multicolumn{1}{c}{$\begin{array}{c}\text { Access to } \\
\text { Access to } \\
\text { Alternative }\end{array}$} & $\begin{array}{c}\text { Access to } \\
\text { People }\end{array}$ & $\begin{array}{c}\text { Access to } \\
\text { Information/ } \\
\text { Involved }\end{array}$ & $\begin{array}{c}\text { Emotionall } \\
\text { Prosedural } \\
\text { Resources }\end{array}$ & $\begin{array}{c}\text { Support } \\
\text { Access to } \\
\text { Solution }\end{array}$ & $\begin{array}{c}\text { Sum of } \\
\text { Scores }\end{array}$ & $\begin{array}{c}\text { Score } \\
\text { (Divided } \\
\text { by 5) }\end{array}$ \\
\hline Parallel structures & 1 & 1 & 2 & 4 & 1 & 9 & 1.80 \\
Process structures & 5 & 5 & 5 & 3 & 5 & 23 & 4.60 \\
High involvement & 5 & 5 & 5 & 4 & 5 & 24 & 4.80 \\
\hline
\end{tabular}

NOTE:A scale from I to 5 is used $(5=$ very high impact on indicator, $3=$ medium impact on indicator, $I=$ very low impact on indicator). The scores for the five indicators are summed, and the sum divided by 5 to produce an average effectiveness score for each alternative. These average effectiveness scores are then used for the Overall Scorecard (see Appendix A). 


\begin{tabular}{|c|c|c|c|c|c|c|c|}
\hline Alternatives & Management & Training & $\begin{array}{l}\text { Performance } \\
\text { Management }\end{array}$ & $\begin{array}{l}\text { Information } \\
\text { Systems }\end{array}$ & $\begin{array}{l}\text { Selection } \\
\text { Systems }\end{array}$ & $\begin{array}{l}\text { Sum of } \\
\text { Scores }\end{array}$ & $\begin{array}{c}\text { Average } \\
\text { Score } \\
\text { (Divided } \\
\text { by 5) }\end{array}$ \\
\hline Parallel structures & 4 & 4 & 5 & 4 & 5 & 22 & 4.40 \\
\hline Process structures & 2 & 2 & 2 & 2 & 2 & 10 & 2.00 \\
\hline High involvement & 1 & 2 & 1 & 1 & 2 & 7 & 1.40 \\
\hline
\end{tabular}

NOTE: A scale from I to 5 is used $(5=$ very low magnitude of change in organizational subsystem, 3 = medium magnitude of change, I = very high magnitude of change). The scores of the five indicators are summed, and the sum divided by 5 to produce an average administrative ease score for each alternative. These average administrative ease scores are then used for the Overall Scorecard (see Appendix A).

TABLE 3: Criterion: Costs

\begin{tabular}{lccc}
\hline & $\begin{array}{c}\text { Lnitial Costs (to Change } \\
\text { Subsystems Referred } \\
\text { to Above } \\
\text { in Administrative } \\
\text { Elternatives }\end{array}$ & $\begin{array}{c}\text { Long Table) } \\
\text { to Upholding } \\
\text { Changes, but Also } \\
\text { to Potential } \\
\text { Financial }\end{array}$ & $\begin{array}{c}\text { Average Score } \\
\text { (Divided } \\
\text { by 2) }\end{array}$ \\
\hline Parallel structures & 4 & Benefits) & 4.00 \\
Process structures & 2 & 4 & 3.00 \\
High involvement & 1 & 4 & 2.50 \\
\hline
\end{tabular}

NOTE: A scale from I to 5 is used ( $5=$ very low costs, $3=$ medium costs, I = very high costs). The scores of the two indicators are summed, and the sum divided by 2 to produce an average costs score for each alternative. These average costs scores are then used for the Overall Scorecard (see Appendix A).

TABLE 4: PRINCE Analysis of Political Feasibility (Fowler, 2009)

\begin{tabular}{|c|c|c|c|c|c|}
\hline & Stakeholders & $\begin{array}{l}\text { Issue Position } \\
\text { (-3 to } 3)\end{array}$ & $\begin{array}{l}\text { Power } \\
\text { (I to 3) }\end{array}$ & $\begin{array}{l}\text { Priority } \\
\text { (I to 3) }\end{array}$ & Total Score \\
\hline \multicolumn{6}{|c|}{ Alternative 1: Parallel Structures } \\
\hline \multirow[t]{3}{*}{ For } & Senior management & 2 & 2 & 1 & 4 \\
\hline & Mid-level management & 2 & 2 & 2 & 8 \\
\hline & Employees & 1 & 2 & 1 & 2 \\
\hline Total & & & & & 14 \\
\hline
\end{tabular}


TABLE 4: (continued)

Alternative 2: Process Structures

\begin{tabular}{llrrrr}
\hline For & Senior management & 3 & 3 & 2 & 18 \\
\hline & Employees & 1 & 2 & 1 & 2 \\
Against & Mid-level management & -2 & 2 & 2 & -8 \\
Total & & & & & 12 \\
\hline
\end{tabular}

Alternative 3: High-Involvement Organization

\begin{tabular}{llrrrr}
\hline For & Senior management & 2 & 3 & 2 & 12 \\
& Employees & 2 & 2 & 2 & 8 \\
Against & Mid-level management & -2 & 3 & 2 & -12 \\
Total & & & & & 8 \\
\hline
\end{tabular}

\section{Conversion of "Political Feasibility" Scores to Scale From I to 5}

Alternative 1: Score of 14 is the highest score, and is therefore attributed the highest score of 5 on a scale from 5 to 1 .

$\rightarrow$ A score of 5 will be given (see Overall Scorecard in Appendix A)

Alternative 2: Score of 12 is $14.29 \%$ lower than highest score of 14, and therefore is attributed the score of 4.29 (which is $14.29 \%$ lower than the score of 5).

$\rightarrow$ A score of 4.29 will be given (see Overall Scorecard in Appendix A)

Alternative 3: Score of 8 is $42.86 \%$ lower than highest score of 14 , and therefore is attributed score of 2.86 (which is $42.86 \%$ lower than the score of 5).

$\rightarrow$ A score of 2.86 will be given (see Overall Scorecard in Appendix A)

\section{References}

Achrol, R. (1997). Changes in the theory of interorganisational relations in marketing: Toward a network paradigm. Journal of the Academy of Marketing Science, 25, 56-71.

Allee, V. (2003). The future of knowledge: Increasing prosperity through value networks. Boston: Butterworth-Heinemann.

Appels, C., van Duin, L., \& Hamann, R. (2006). Institutionalising corporate citizenship: The case of Barloworld and its employee value creation process. Development Southern Africa, 23, 241-250.

Aronowitz, S., \& Giroux, H. A. (2000). The corporate university and the politics of education. Educational Forum, 64, 332-339.

Arumugam, K., Craven, A., \& Statum, J. (2007). Education for change in South Africa's auto industry. In A. Dayal-Gulati \& M. W. Finn (Eds.), Global corporate citizenship (pp. 121-132). Evanston, IL: Northwestern University Press.

Aßländer, M. (2006). Prize for business ethics 2006 awarded to Novartis AG. Forum Wirtschaftsethik, 14, 4-7.

Bird, F. B., \& Waters, J. A. (1989). The moral muteness of managers. California Management Review, 32, 73-88. 
Blumenthal, B., \& Haspeslagh, P. (1994). Toward a definition of corporate transformation. Sloan Management Review, 35, 101-107.

Boris, J., Davis, K., Gross, M., Keintz, J., \& Totten, J. (2007). Labor standards in Thailand: The players and their impacts. In A. Dayal-Gulati \& M. W. Finn (Eds.), Global corporate citizenship (pp. 27-39). Evanston, IL: Northwestern University Press.

Boston College Center for Corporate Citizenship. (2007). The state of corporate citizenship 2007. Boston: Boston College Center for Corporate Citizenship.

Brinkerhoff, R. O. (2003). The success case method: How to quickly find out what's working and what's not. San Francisco: Berrett Kohler.

Burke, E. M. (2005). Managing a company in an activist world: The leadership challenge of corporate citizenship. Westport, CT: Praeger.

Castka, P., \& Balzarova, M. A. (2008). The impact of ISO 9000 and ISO 14000 on standardisation of social responsibility: An inside perspective. International Journal of Production Economics, 113, 74-97.

Cha, H., Cline, P., Liu, L., Meek, C., \& Villagomez, M. (2007). Avon in Brazil: Direct selling and economic empowerment. In A. Dayal-Gulati \& M. W. Finn (Eds.), Global corporate citizenship (pp. 89-96). Evanston, IL: Northwestern University Press.

Chan, S., Gupta, D., Palamountain, K., \& Saha, A. (2007). Sustainable foundations for HIV/AIDS care: Treatment and delivery in South Africa. In A. Dayal-Gulati \& M. W. Finn (Eds.), Global corporate citizenship (pp. 177-187). Evanston, IL: Northwestern University Press.

Cluff, J., Knuckle, A., Libaridian, C., Smith, R. D., \& Williams, W. (2007). Preventing labor-standards "explosion" in Thailand and Vietnam. In A. Dayal-Gulati \& M. W. Finn (Eds.), Global corporate citizenship (pp. 57-74). Evanston, IL: Northwestern University Press.

Coplin, W. D., \& O'Leary, M. K. (1981). Basic policy studies skills. Croton-on-Hudson, NY: Policy Studies Associates.

Coplin, W. D., \& O’Leary, M. K. (1998). Basic policy studies skills (3rd ed.). Croton-on-Hudson, NY: Policy Studies Associates.

Crane, A., \& Matten, D. (2008). Incorporating the corporation in citizenship: A response to Néron and Norman. Business Ethics Quarterly, 18, 27-33.

Cummings, T. G., \& Worley, C. G. (2005). Organization development and change. Mason, OH: SouthWestern.

Curd, A., Julian, A., Sabow, A., \& Seligman, L. (2007). The impact of foreign direct investment on Chinese women. In A. Dayal-Gulati \& M. W. Finn (Eds.), Global corporate citizenship (pp. 77-88). Evanston, IL: Northwestern University Press.

Day, D. V. (2000). Leadership development: A review in context. Leadership Quarterly, 11, 581-613.

Detomasi, D. A. (2007). The multinational corporation and global governance: Modelling global public policy networks. Journal of Business Ethics, 71, 321-334.

Dow Jones Sustainability Index. (2006). Sustainability leader. Retrieved January 28, 2007, from http://www.sustainability-index.com/djsi_pdf/Bios07/Novartis_07.pdf

The Economist Intelligence Unit. (2008). Corporate citizenship: Profiting from a sustainable business. RetrievedDecember 1,2008, fromhttp://viewswire.eiu.com/report_dl.asp?mode=fi\&fi=1353979920 .PDF\&rf $=0$

Eisenbach, R., Watson, K., \& Pillai, R. (1999). Transformational leadership in the context of organization change. Journal of Organizational Change Management, 12, 80-89.

Epstein, E. M. (1989). Business ethics, corporate good citizenship and the corporate social policy process: A view from the United States. Journal of Business Ethics, 8, 583-595.

Epstein, M. J., \& Roy, M.-J. (2001). Sustainability in action: Identifying and measuring the key performance drivers. Long Range Planning, 34, 585-604.

Ethisphere. (2007). 2007 world's most ethical companies: Ranking. New York: Author.

European Commission. (2006). Communication from the Commission to the European Parliament, the Council, and the European Economic and Social Committee: Implementing the partnership for growth and jobs: Making Europe a pole of excellence on corporate social 
responsibility. Retrieved November 21, 2008, from http://eur-lex.europa.eu/LexUriServ/ LexUriServ.do?uri=COM:2006:0136:FIN:EN:PDF

Fenwick, T. (2007). Developing organizational practices of ecological sustainability: A learning perspective. Leadership \& Organization Development Journal, 28, 632-645.

Fenwick, T., \& Bierema, L. (2008). Corporate social responsibility: Issues for human resource development professionals. International Journal of Training and Development, 12, 24-35.

Fisher, C. (2001). Managers' perception of ethical codes: Dialectics and dynamics. Business Ethics: A European Review, 10, 145-156.

Foote, M. F., \& Ruona, W. E. A. (2008). Institutionalizing ethics: A synthesis of frameworks and the implications for HRD. Human Resource Development Review, 7, 292-308.

Forrester, R. (2000). Empowerment: Rejuvenating a potent idea. Academy of Management Executive, $14,67-81$.

Fourie, A., \& Eloff, T. (2005). The case for collective business action to achieve systems change. Journal of Corporate Citizenship, 18, 39-48.

Fowler, F. C. (2009). Policy studies for educational leaders: An introduction (3rd ed.). Boston: Pearson.

Frisque, D. A., \& Kolb, J. A. (2008). The effects of an ethics training program on attitude, knowledge, and transfer of training of office professionals: A treatment- and control-group design. Human Resource Development Quarterly, 19, 35-53.

FTSE. (2006). FTSE4Good index series. Retrieved January 27, 2008, from http://www.ftse.com/ Indices/FTSE4Good_Index_Series/Downloads/F4G_5Year_Review.pdf

Fussler, C. (2004). Responsible excellence pays! Journal of Corporate Citizenship, 16, 33-44.

Genest, C. M. (2005). Cultures, organizations and philanthropy. Corporate Communications: An International Journal, 10, 315-327.

Gibbons, S., Lau, M., McAuliffe, S., \& Watson, J. (2007). Ecoefficiency in Chile and Peru. In A. DayalGulati \& M. W. Finn (Eds.), Global corporate citizenship (pp. 217-232). Evanston, IL: Northwestern University Press.

Glazebrook, M. (2005). The social construction of corporate citizenship. Journal of Corporate Citizenship, 17, 53-67.

Goodman, P., Devadas, R., \& Hughson, T. (1988). Groups and productivity: Analyzing the effectiveness of self-managing teams. In J. Campbell \& R. Campbell (Eds.), Productivity in organizations (pp. 295-325). San Francisco: Jossey-Bass.

Graafland, J., \& van de Ven, B. (2006). Strategic and moral motivation for corporate social responsibility. Journal of Corporate Citizenship, 22, 111-123.

Greiner, L., \& Bhambri, A. (1989). New CEO intervention and dynamics of deliberate strategic change. Strategic Management Journal, 10, 67-86.

Greve, J. (2008). Healthcare in developing countries and the role of business: A global governance framework to enhance the accountability of pharmaceutical companies. Corporate Governance, $8,490-505$.

Grit, K. (2004). Corporate citizenship: How to strengthen the social responsibility of managers? Journal of Business Ethics, 53(1-2), 97-106.

Guthrie, J. (2001). High-involvement work practices, turnover, and productivity: Evidence from New Zealand. Academy of Management Journal, 44, 180-191.

Hall, J. (2000). Survey of employee access. The Woodlands, TX: Teleometrics International.

Hanson, M. (2006). Transnational corporations as educational institutions for national development: The contrasting cases of Mexico and South Korea. Comparative Education Review, 50, 625-650.

Hargett, T. R., \& Williams, M. F. (2009). Wilhelmsen Shipping Company: Moving from CSR tradition to CSR leadership. Corporate Governance, 9, 73-82.

Henderson, J. C., \& Lee, S. (1992). Managing I/S design teams: A control theories perspective. Management Science, 38, 757-777.

Hernez-Broome, G., \& Hughes, R. J. (2004). Leadership development: Past, present, and future. Human Resource Planning, 27, 24-32.

Herzig, S. E., \& Jimmieson, N. L. (2006). Middle managers' uncertainty management during organizational change. Leadership and Organization Development Journal, 27, 628-645. 
Holton, E. F., III. (1996). The flawed 4-level evaluation model. Human Resource Development Quarterly, 7, 5-21.

Honeycutt, A. (1989). The key to effective quality circles. Training and Development Journal, 43, 81-84.

Keohane, R. O. (2008). Complex accountability and power in global governance: Issues for global business. Corporate Governance, 8, 361-367.

Kirkpatrick, D. L. (1959). Techniques for evaluating training programs. Journal of American Society of Training Directors, 13, 3-26.

Kirkpatrick, D. L. (2004). A T-D classic: How to start an objective evaluation of your training program. Training + Development, 58, 16-18.

Kjonstad, B., \& Willmott, H. (1995). Business ethics: Restrictive or empowering? Journal of Business Ethics, 14, 445-464.

Kobrin, S. J. (2008). Globalization, transnational corporations and the future of global governance. In A. G. Scherer \& G. Palazzo (Eds.), Handbook of research on global corporate citizenship (pp. 249-272). Cheltenham, UK: Edward Elgar.

Lacy, P., \& Pickard, S. (2008). Managing risk and opportunity. Journal of Corporate Citizenship, 30, 139-146.

Lai, H., Lippert, M., Silva, G., Steinberg, A., Sthankiya, P., \& Twitchell, J. (2007). Flex-fuel technology in Brazil. In A. Dayal-Gulati \& M. W. Finn (Eds.), Global corporate citizenship (pp. 233-250). Evanston, IL: Northwestern University Press.

Lau, C. M., Kilbourne, L., \& Woodman, R. (2003). A shared schema approach to understanding culture change. In W. Pasmore \& R. Woodman (Eds.), Research on organizational change and development (Vol. 14). Greenwich, CT: JAI Press.

Lawler, E. E., Mohrman, S. A., \& Benson, G. (2001). Organizing for high performance organizations: Employee involvement, TQM, reengineering, and knowledge management in the Fortune 1000: The CEO report. San Francisco: Jossey-Bass.

Leisinger, K. M. (2003). Opportunities and risks of the United Nations Global Compact. Journal of Corporate Citizenship, 11, 113-131.

Leskiw, S.-L., \& Singh, P. (2007). Leadership development: Learning from best practices. Leadership \& Organization Development Journal, 28, 444-464.

Levitt, B., \& March, J. G. (1988). Organizational learning. Annual Review of Sociology, 14, 319-340.

Levy, D. L., \& Kaplan, R. (2008). Corporate social responsibility and theories of global governance. In A. Crane, A. McWilliams, D. Matten, J. Moon, \& D. S. Siegel (Eds.), The Oxford handbook of corporate social responsibility (pp. 432-451). New York: Oxford University Press.

Logsdon, J. M., \& Wood, D. J. (2002). Business citizenship: From domestic to global level of analysis. Business Ethics Quarterly, 12, 155-187.

Lougee, B., \& Wallace, J. (2008). The corporate social responsibility (CSR) trend. Journal of Applied Corporate Finance, 20, 96-108.

Maerki, H. U. (2008). The globally integrated enterprise and its role in global governance. Corporate Governance, 8, 368-374.

Majchrzak, A., Rice, R. E., Malhotra, A., King, N., \& Ba, S. (2000). Technology adaptation: The case of a computer-supported inter-organizational virtual team. MIS Quarterly, 24, 569-600.

Manga, J. E., \& Mirvis, P. (2005). Integration: Critical link for corporate citizenship: Strategies and real cases from 8 companies. Boston: Boston College Center for Corporate Citizenship.

Maon, F., Lindgreen, A., \& Swaen, V. (in press). Designing and implementing corporate social responsibility: An integrative framework grounded in theory and practice. Journal of Business Ethics.

Marsden, C. (2000). The new corporate citizenship of big business: Part of the solution to sustainability? Business \& Society Review, 105, 9. 
Matten, D., Crane, A., \& Chapple, W. (2004). Behind the mask: Revealing the true face of corporate citizenship. Journal of Business Ethics, 45(1-2), 109-120.

McDonnell, L. M., \& Elmore, R. F. (1987). Getting the job done: Alternative policy instruments. Educational Evaluation and Policy Analysis, 9, 133-152.

McLean, G. N. (2004). National human resource development: What in the world is it? Advances in Developing Human Resources, 6, 269-275.

McLean, G. N. (2006a). National human resource development: A focused study in transitioning societies in the developing world. Advances in Developing Human Resources, 8, 3-11.

McLean, G. N. (2006b). Organization development: Principles, processes, performances. San Francisco: Berrett-Koehler.

Mirvis, P. H., \& Manga, J. (2007). Integrating corporate citizenship: Leading from the middle. Boston: Boston College Center for Corporate Citizenship.

Mohrman, S. A., Cohen, S. G., \& Mohrman, A. M. (1995). Designing team-based organizations: New forms for knowledge work. San Francisco: Jossey-Bass.

Mohrman, S. A., Klein, J. A., \& Finegold, D. (2003). Managing the global product development network. In C. B. Gibson \& S. G. Cohen (Eds.), Virtual teams that work: Creating conditions for virtual team effectiveness (pp. 37-58). San Francisco: Jossey-Bass.

Moon, J., Crane, A., \& Matten, D. (2005). Can corporations be citizens? Corporate citizenship as a metaphor for business participation in society. Business Ethics Quarterly, 15, 429-453.

Morsing, M., \& Oswald, D. (2009). Leading for sustainability: Management control systems and organizational culture in Novo Nordisk A/S. Corporate Governance, 9, 83-99.

Netteland, G., Wasson, B., \& Mørch, A. I. (2007). E-learning in a large organization: A study of the critical role of information sharing. Journal of Workplace Learning, 19, 392-411.

Nonaka, I. (1994). A dynamic theory of organizational knowledge creation. Organization Science, 5, 14-37.

Novartis. (2007). Policy on corporate citizenship. Retrieved March 3, 2008, from http://www .corporatecitizenship.novartis.com/downloads/managing-cc/02_2003_policy_on_corporate citizenship.pdf

Novartis. (2008a). Integrity and compliance. Retrieved January 2, 2008, from http://www .corporatecitizenship.novartis.com/business-conduct/business-practice/integrity-compliance.shtml

Novartis. (2008b). Responsible business practice. Retrieved January 2, 2008, from http://www .novartis.com/about-novartis/corporate-citizenship/business-conduct/business-practice.shtml

OECD. (2001). The OECD guidelines for multinational enterprises. Retrieved November 21, 2008, from http://www.oecd.org/dataoecd/12/21/1903291.pdf

Oketch, M. O. (2005). The corporate stake in social cohesion. Peabody Journal of Education, 80, $30-52$.

Pfeffer, J. (1995). Producing sustainable competitive advantage through the effective management of people. Academy of Management Executive, 9, 55-69.

Phillips, P. P. (2007). The ROI fieldbook: Strategies for implementing ROI in HR and training. Boston: Butterworth-Heinemann.

Pinkston, T. S., \& Carroll, A., B. (1994). Corporate citizenship perspectives and foreign direct investment in the U.S. Journal of Business Ethics, 13, 157-169.

Pirsch, J., Gupta, S., \& Grau, S. L. (2007). A framework for understanding corporate social responsibility programs as a continuum: An exploratory study. Journal of Business Ethics, 70, 125-140.

Poltauer, J. (2004). Gesellschaftliche Integration durch Corporate Citizenship? Diskussionspapiere zum Nonprofit-Sektor, 24, 1-34.

Porter, T. B. (2008). Managerial applications of corporate social responsibility and systems thinking for achieving sustainability outcomes. Systems Research and Behavioral Science, 25, 397-411. 
Post, J. E. (2000). Moving from geographic to virtual communities: Global corporate citizenship in a dot.com world. Business \& Society Review, 105, 27-46.

Post, J. E. (2002). Global corporate citizenship: Principles to live and work by. Business Ethics Quarterly, 12, 143-153.

Purvis, R. L., Sambamurthy, V., \& Zmud, R. W. (2001). The assimilation of knowledge platforms in organizations: An empirical investigation. Organization Science, 12, 117-135.

Scherer, A. G., \& Palazzo, G. (2008). Globalization and corporate social responsibility. In A. Crane, A. McWilliams, D. Matten, J. Moon, \& D. S. Siegel (Eds.), The Oxford handbook of corporate social responsibility (pp. 413-431). New York: Oxford University Press.

Sleeper, B., Schneider, K., Weber, P., \& Weber, J. (2006). Scale and study of student attitudes toward business education's role in addressing social issues. Journal of Business Ethics, 68, 381-391.

Smith, N. C., Simpson, S. S., \& Chun-Yao, H. (2007). Why managers fail to do the right thing: An empirical study of unethical and illegal conduct. Business Ethics Quarterly, 17, 633-667.

Sturchio, J. L. (2008). Business engagement in public programs: The pharmaceutical industry's contribution to public health and the millennium development goals. Corporate Governance, $8,482-489$.

United Nations. (2008). United Nations Global Compact. Retrieved November 21, 2008, from http://www.unglobalcompact.org/docs/news_events/8.1/GC_brochure_FINAL.pdf

van Beurden, P., \& Gössling, T. (2008). The worth of values: A literature review on the relation between corporate social and financial performance. Journal of Business Ethics, 82, 407-424.

van de Ven, A. H., \& Poole, M. S. (1995). Explaining development and change in organizations. Academy of Management Review, 20, 510-540.

van Tulder, R., \& van der Zwart, A. (2006). International business-society management: Linking corporate responsibility and globalization. New York: Routledge.

Vian, T., Richards, S. C., McCoy, K., Connelly, P., \& Feeley, F. (2007). Public-private partnerships to build human capacity in low income countries: Findings from the Pfizer program. Human Resources for Health, 5(8). Retrieved March 9, 2009, from http://www.human-resourceshealth.com/content $/ 5 / 1 / 8$

Vidaver-Cohen, D., \& Altman, B. W. (2000). Corporate citizenship in the new millennium: Foundation for an architecture of excellence. Business \& Society Review, 105, 145-168.

Waddock, S. (2004). Parallel universes: Companies, academics, and the progress of corporate citizenship. Business \& Society Review, 109, 5-42.

Waddock, S., \& Smith, N. (2000). Relationships: The real challenge of corporate global citizenship. Business \& Society Review, 105, 47-62.

Welford, R. (2005). Corporate social responsibility in Europe, North America and Asia. Journal of Corporate Citizenship, 17, 33-52.

Wilcox, T. (2006). Human resource development as an element of corporate social responsibility. Asia Pacific Journal of Human Resources, 44, 184-196.

Wood, D. J., \& Logsdon, J. M. (2008). Business citizenship as metaphor and reality. Business Ethics Quarterly, 18, 51-59.

World Bank. (2008). Business competitiveness, \& development. Retrieved November 21, 2008, from http://go.worldbank.org/SV66UOJ3V0

Young, I. M. (2006). Responsibility and global justice: A social connection model. Social Philosophy and Policy, 23, 102-130.

Zand, D. (1974). Collateral organization: A new change strategy. Journal of Applied Behavioral Science, 10, 63-89.

Zimmerli, W. C., \& Holzinger, M. (2006). Transnational corporations and the global mindset. In J. Hennigfeld, M. Pohl, \& N. Tolhurst (Eds.), The ICCA handbook on corporate social responsibility (pp. 115-126). West Sussex, UK: John Wiley.

Zlotkowski, E. (2004). Opportunity for all: Linking service-learning and business education. Journal of Business Ethics, 15, 5-19. 
Ingo Stolz is a doctoral student and graduate research assistant in educational policy and administration at the University of Minnesota. He is the founder and head of SGOCI, a consulting firm specializing in international organization development and global corporate citizenship; he has worked in Russia, China, Switzerland, and Germany. As a fellow of the Bosch Foundation and as a recipient of a teaching exchange scholarship awarded by the Albert-Ludwigs University of Freiburg, Germany, he has been teaching and lecturing for five years at universities in the US, Germany, Russia, and China.E-mail: stolz016@ umn.edu.

Gary N. McLean is a senior professor and executive director of International HRD Programs, Texas A\&M University, and professor emeritus, work and human resource development, University of Minnesota. He has served as editor in many journals and as president of the Academy of HRD and as president of the International Management Development Association. His research interests include organization development and national, regional, social, and internationalHRD.E-mail:gmclean@tamu.edu. 